\title{
ДОСВІД ВИКЛАДАННЯ ФІЗІОЛОГІЇ СТУДЕНТАМ СПЕЦАЛЬНОСТІ "ПЕДІАТРІЯ" ЗА КРЕДИТНО-МОДУЛЬНОЮ СИСТЕМОЮ В БУКОВИНСЬКОМУ ДЕРЖАВНОМУ МЕДИЧНОМУ УНІВЕРСИТЕТІ
}

В. В. Гордіснко

Буковинський державний медичний університет, м. Чернівизі

\section{EXPERIENCE OF TEACHING STUDENTS PHYSIOLOGY IN SPECIALTY "PEDIATRICS" ACCORDING TO THE CREDIT-MODULAR SYSTEM IN BUKOVYNA STATE MEDICAL UNIVERSITY}

\author{
V. V. Hordiyenko
}

\author{
Bukovyna State Medical University, Chernivtsy
}

\begin{abstract}
Висвітлено шляхи і методи профільної підготовки студентів спеціальності “Педіатрія” на кафедрі фізіології Буковинського державного медичного університету при навчанні за кредитно-модульною системою та значення набутих знань $з$ фізіології для професійної діяльності лікаря-педіатра.
\end{abstract}

Ways and methods for profile training of students in specialty "Pediatrics" at the Department of Physiology of Bukovyna State Medical University by teaching according to the credit-modular system and the importance of acquired knowledge of physiology for professional activity of pediatrist was interpreted.

Вступ. Перед вищою медичною школою на сучасному етапі одним із головних завдань є підвищення якості підготовки кваліфікованих спеціалістів, їх професіоналізм і конкурентоспроможність. Згідно 3 Національною доктриною розвитку освіти, розбудова системи освіти в Україні зорієнтована на європейські стандарти, які репрезентують багаторівневість, безперервність, доступність, ефективність та якість [1].

Приєднання України до Болонського процесу потребує нової сучасної концепції підготовки фахівців, впровадження в навчальний процес нових вдосконалених форм навчання та контролю за знаннями, вміннями й навичками студентів. Впровадження кредитно-модульної системи організації навчального процесу передбачає структурування матеріалу дисципліни на модулі з перевіркою якості засвоєння студентами кожного модуля, використання ширшої шкали оцінювання знань, підвищення об' єктивності оцінювання, стимулювання систематичної роботи студентів упродовж семестру, збільшення питомої ваги самостійної роботи, запровадження здорової конкуренції в навчанні [2].

Значні зміни, що сталися в системі вищої медичної освіти, зумовили необхідність перегляду методології

(C) В. В. Гордієнко викладання усіх дисциплін, у тому числі й фізіології. При викладанні фізіологіїза новими вимогами постійно вдосконалюється організація навчального процесу, система оцінювання знань та вмінь студентів, форми заохочування і стимуляції їх навчальної діяльності [3].

Основна частина. Згідно з галузевою програмою для студентів BM3 освіти III-IV рівнів акредитації (MO3 України, К., 2006 р.) на вивчення фізіології для спеціальності "Педіатрія", як і “Лікувальна справа", виділено 10 кредитів ECTS (300 год), з яких 200 год складає аудиторна підготовка (лекції 60 год, практичні заняття - 140 год) та 100 год - самостійна робота студента (СРC). Вивчення дисципліни відбувається на 2 курсі (III-IV семестри) і здійснюється за кредитно-модульною системою відповідно до вимог Болонського процесу. Програмаз фізіології структурована на 4 модулі, до складу яких входять блоки змістових модулів: 1 - “Загальна фізіологія"; 2 - “Фізіологія вісцеральних систем: крові, кровообігу, дихання"; 3 - “Фізіологія вісцеральних систем: енергетичного обміну, терморегуляції, травлення, виділення”; 4 - “Вищі інтегративні функції'. Підсумковий модульний контроль проводиться по завершенні вивчення всіх тем змістових модулів. Форма проведення підсумкового модульного контролю є стандарти- 
зованою і охоплює контроль теоретичної і практичної підготовки.

Тематичні плани лекцій, практичних занять, СРС забезпечують реалізацію у навчальному процесі всіх тем, які включені до складу змістових модулів. Теми лекційного курсу розкривають проблемні питання відповідних розділів фізіології. Практичні заняття за методикою їх організації є лабораторними й передбачають експериментальний практикум, дослідження функцій здорової людини, вирішення ситуаційних задач, що мають експериментальне або клініко-фізіологічне спрямування. Студентам прищеплюється вміння правильно аналізувати отримані результати основних та допоміжних методів дослідження органів i систем як у дорослих, так і в дітей. Підсумковий модульний контроль здійснюється по завершенні вивчення модуля. Оцінка успішності студента з дисципліни є рейтинговою і виставляється за багатобальною шкалою як середня арифметична оцінка засвоєння відповідних модулів і має визначення за системою ECTS та традиційною шкалою, прийнятою в Україні.

Методичним путівником студентам для набуття знань, опанування умінь і практичних навичок із предмета є виданий колективом кафедри фізіології навчально-методичний посібник, у якому весь курс фізіології подано у вигляді методичних вказівок до всіх практичних і підсумкових занять [4]. Кожна методична вказівка містить обгрунтування теми заняття, навчальну мету (знати, вміти, опанувати), завдання для експериментальної роботи з описом ходу виконання, рекомендації щодо оформлення отриманих результатів та висновків. Наведено також перелік завдань для самостійної роботи, самоконтролю та контрольні питання теми. У кінці кожної вказівки подано основну (із зазначенням сторінок) і додаткову літературу. У додатках містяться таблиці, рисунки, а також перелік контрольних питань для підготовки студентів до підсумкових модулів із фізіології (17 змістових) та перелік практичних робіт і завдань до них.

На кожному практичному занятті при виконанні завдань СРС у лекційному курсі для студентів спеціальності "Педіатрія", який читається окремому потоку, зосереджується увага на особливостях функціонування всіх органів і систем у дитячому віці (центральна, автономна нервова система, серцево-судинна система, дихання, травлення, виділення тощо), що так необхідно в практичній діяльності лікаря-педіатра.

За останні роки при підготовці майбутніх лікарів значно зросло використання в навчальному процесі електронних технічних засобів освіти. Для забезпе- чення безперервного зворотного зв'язку між викладачем і студентом у пригоді стають сучасні засоби комунікації та інформаційні технології [5]. Практично незамінними вони стають при організації позааудиторної СРС, забезпечуючи дистанційну взаємодію між суб'єктами навчального процесу.

3 метою оптимізації навчального процесу та покращання самопідготовки до практичних занять із фізіології на сервері дистанційного навчання Буковинського державного медичного університету в системі "MOODLE" викладачами кафедри розміщено навчально-методичні та наочні матеріали (лекційні презентації, відеофільми, ситуаційні та тестові завдання) 3 дисципліни “Фізіологія”. Система управління навчання "MOODLE" дозволяє викладачу не тільки подати навчальний матеріал, а й контролювати процес підготовки студентів до практичних занять. При цьому викладач має доступ до такої інформації: перелік студентів групи, які використовували електронний навчальний курс при підготовці до заняття, які матеріали були використані студентом, скільки часу студент витратив на роботу з тим чи іншим ресурсом, наскільки якісно студент опанував теоретичний матеріал (за результатами самоконтролю). Таким чином, викладач володіє кількісними та якісними показниками результатів позааудиторної роботи окремого студента та групи в цілому.

Колективом кафедри налагоджено співпрацю з кафедрою фізіології людини і тварин Національного університету ім. Т. Г. Шевченка, що сприяло впровадженню альтернативних методів використання лабораторних тварин і проведення дослідів. Отримана на електронному носієві програма “Общая физиология. Лигатуры Станиуса” використовується у навчальному процесі студентів спеціальності "Педіатрія" й інших спеціальностей. Досягнуто домовленість на отримання серій інших програм віртуального лабораторного практикуму. Кафедральна відеотека поповнюється також навчальними відеофільмами з опорної кафедри (кафедра нормальної фізіологіїНаціонального медичного університету імені О. О. Богомольця) та власного виробництва.

Кафедра щороку доповнює базу ліцензійного інтегрованого іспиту "Крок-1" новими тестовими завданнями з фізіології для студентів усіх спеціальностей, у тому числі й “Педіатрія". Оновлені варіанти тестових завдань із підготовки до складання ліцензійних іспитів “Крок-1" у тренінговому та контролюючому режимах розміщуються у відповідних електронних навчальних курсах на сервері дистанційного навчання БДМУ. Проведення діагностично-тренінго- 
вих тестувань сприяє більш якісній підготовці й написанню студентами “Крок-1. Загальна лікарська підготовка" на третьому курсі. Результати діагностично-тренінгових тестувань і ліцензійних інтегрованих іспитів обговорюються й аналізуються на засіданнях кафедри.

Важливим елементом навчання є самостійна робота студента (СРС), яка передбачає втілення в життя принципу індивідуального підходу, надання максимальної можливості для розвитку особистісних і професійних якостей, творчої індивідуальності майбутніх фахівців. Самостійна робота з фізіологіі, яка передбачає засвоєння практичних навичок без участі викладача, ставить перед студентом проблему, мотивує до опрацювання додаткової літератури. Можливості студентів при реалізації самостійної роботи залежать від їх індивідуально-типологічних особливостей. Саме в самостійній роботі проявляється активність особистості, яка дозволяє формувати самоорганізованість та самоконтроль [1].

Навчальними галузевими програмами і планами передбачена поетапна наступність набуття знань у процесі формування спеціаліста-медика. Якщо вивчення фізіології грунтується на отриманих інтегративних знаннях із морфологічних дисциплін, медичної біології, фізики, медичної, біологічної, біоорганічної хімії тощо, то отримані базові знання з фізіології закладають основи подальшого засвоєння студентами патофізіології, фармакології, пропедевтики клінічних дисциплін.

\section{Література}

1. Нужненко К. Соціально-економічні позиції української освіти в європейському просторі / К. Нужненко // Вища школа. $-2012 .-$ С. 25-32.

2. Казаков В. М. Новітні тенденції розвитку європейської медичної освіти / В. М. Казаков, О. М. Талалаєнко, М. Б. Первак // Мед. освіта. -2009. -№ 2. - С. 40-44.

3. Досвід викладання фізіолології за кредитно-модульною системою в Буковинському державному медичному університеті / І. Р. Тимофійчук, С. Б. Семененко, В.В.Гордієнко, В. І. Швець // Кредитно-модульна система організації навчального процесу у вищих медичних (фармацевтичному) навчальних закладах України на новому етапі: матеріали Х ювілейної Всеукр. навч.-наук. конф. 3 міжнар. участю. - Тернопіль, 2013. -С. 510-513.
Отримане на кафедрі фізіології усвідомлення того, що дитячий організм ще перебуває на стадії формування, має фізіологічні особливості, більшість захисних і пристосувальних механізмів розвинуті недостатньо, в подальшому при вивченні фармакологіï, фармакотерапії студентам легше зрозуміти та засвоїти особливості дії ліків на дитячий організм [6]. Набуті студентами знання з фізіології та практичні навички закріплюються й поглиблюються на клінічних кафедрах педіатричного профілю [7].

Висновки: 1. Упровадження кредитно-модульної системи в навчальний процес із збільшенням питомої ваги самостійної роботи, використанням новітніх освітніх технологій, постійним контролем знань, набуттям професійних умінь і навичок є необхідними складовими якісної підготовки студентів, що сприяє стимуляції творчого потенціалу майбутнього висококваліфікованого спеціаліста-медика.

2. Для впровадження новітніх технологій та сучасних підходів до них необхідна достатня підготовка як викладачів, так і студентів.

3. Грунтовне та поетапно систематизоване вивчення й усвідомлення студентами особливостей фізіології дитячого організму, яке закладається ще на кафедрі фізіології, сприяє професійній компетентності майбутніх лікарів-педіатрів, робить їх конкурентоспроможними спеціалістами на європейському ринку.

4. Фізіологія. Навчально-методичний посібник / за ред. Г. І. Ходоровського, С. С. Ткачук, В. І. Швеця. - Чернівці: Видавництво БДМУ, 2013. -547 с.

5. Бойчук Т. М. Досвід впровадження інформаційно-комунікаційних технологій у навчальному процесі Буковинського державного медичного університету / Т. М. Бойчук, І. В. Геруш, В. М. Ходоровський // Мед. освіта. -2012. -№ 2. - С. 64-67.

6. Фармакологія. Підручник для медичних факультетів / за ред. І. С. Чекмана. - Вінниця : Нова Книга, 2011. - 784 с.

7. Уніфікований контроль за самостійною підготовкою студентів із педіатрії / Т. В. Сорокман, С. В. Сокольник, М. Г. Гінгуляк, Н. І. Підвисоцька// Актуальні питання вищої медичної та фармацевтичної освіти: досвід, проблеми, інновації та сучасні технології: мат-ли навч. метод. конф. Чернівці, 2013.-С. 55-56. 